\title{
Application of Collaborative Learning Method: Interactive and Online Learning to Improve Effective Communication Based on Online Media and Website Government Public Relations Learning
}

\author{
Dr. Emeraldy Chatra, M.Ikom ${ }^{1 *}$ Ilham Havifi, M.Ikom² $^{2}$ \\ ${ }^{1}$ Communications Science, Faculty of Social and Political Science, Andalas University, Padang 25164, Indonesia \\ ${ }^{2}$ Communications Science, Faculty of Social and Political Science, Andalas University, Padang 25164, Indonesia \\ *Corresponding email. Email: emeraldy1962@gmail.com
}

\begin{abstract}
The Government Public Relations or G-PR course which is the object of research is a course in the Department of Communication, Andalas University. This course not only provides hard skills and but also soft skills with a combination of theory and practice where the portion of practice is comparable to the theory of science. To achieve its objectives the G-PR uses collaborative learning methods between online learning and interactive learning. With this method students are expected to have an understanding of the relationship between public relations activities directly in the G-PR study in the era of technology 4.0, including understanding various elements of government public relations, identifying differences and similarities in practice and phenomena in government public relations studies. Students are also expected to be able to analyze, both conceptually and practically, to assess the development of the existing public relations system. Research on the development of education quality assurance (PPMP) from the G-PR course uses qualitative methods in analyzing data, with the main idea that researchers are also directly involved in the learning process and then consciously carry out the learning program that has been designed to completion. The research was conducted in two cycles, each cycle carried out following procedures, namely planning, acting, observing and reflecting. Through these two cycles, it can be observed that the students' ability increases using various media. The first cycle with interactive learning assessment to the field and the second cycle online learning with the assessment reporting stage using the i-learn portal.
\end{abstract}

Keywords: Government Public Relations, Collaborative Learning, Assessment

\section{INTRODUCTION}

Research on development and quality assurance of education is very important to be carried out by lecturers at Andalas University in the era of digital technology development as it is today. Technology that supports education is very important to be applied as one of the steps to get educational attainment as stipulated by Kepmendikbud No.3 of 2020 that the competency standards of graduates include attitudes, knowledge, special skills, and general skills, so that students have broad enough expertise in mastering technology and solution thinking.

To achieve the best graduate competencies, courses in the Communication Science Department are oriented to every form of competency in the curriculum. This competency is considered to be very much needed by the community, both in terms of services and skills to resolve crises that occur in the community using a crisis management approach.
The Government Public Relations or the G-PR is a course in the Department of Communication which not only develops hard skills but also soft skills, namely a combination of theory and practice where the portion of practice is balanced with theory. Elements of learning outcomes include knowledge and methods of implementing the G-PR, attitudes and values in lectures. The learning method developed to support learning outcomes is in the form of group discussions, article reviews, working paper presentations, case studies and questions and answers related to the G-PR. For the development of this subject, research is needed that can produce good RPS, dynamic learning methods and technologies, and other elements that can create student independence.

To achieve the objectives of lecture the G-PR uses collaborative learning method, which is a combination of online learning with interactive learning. Thus students are expected to have an understanding of government public relations in the era of technology 4.0 which includes an understanding of various elements of 
the G-PR, as well as similarities and different perspectives in government public relations studies. Students are also expected to be able to analyze, both conceptually and practically, and assess the development of the existing public relations system.

From this lecture process, students are also expected to be able to write good reviews/essays, be able to present the results of their thoughts clearly, be confident, independent, have discipline, ethics, and be able to work in teams. In addition, students are assigned to visit government agencies to discuss with government public relations officials and directly observe community service practices. From the various obstacles found, the right learning method can be formulated, learning technology that supports the teaching and learning process, and the right assessment formula so that the expected output can be achieved. So that after completing the teaching and learning process in the G-PR course, $90 \%$ of students get A or A- and only $10 \% \mathrm{~B}+$.

Based on the description above, the researcher formulates a method to develop appropriate learning so that the quality of education in learning the G-PR courses can be guaranteed. The relevant research question for the description above is "What is the form of application of collaborative learning methods based on online media and websites in the G-PR lectures that can improve the quality of learning?"

\section{LITERATURE REVIEW}

The meaning of collaborating on Collaborative Learning Techniques is working together with others. Collaborative learning practice means working in pairs or small groups to achieve shared learning goals. Collaborative learning means learning through group work, not learning in isolation. Nizar, (2008 in Housnan, 2014) Collaborative Learning is "a group learning process where each member contributes information, experiences, ideas, attitudes, opinions, abilities, and skills, to jointly improve the understanding of all members".

Collaborative Learning is based on the idea that learning activities should encourage and assist students in building knowledge so as to achieve deep understanding. Furthermore, studying in groups, in addition to increasing students' motivation and interest, it can also improve and develop creative thinking.

Learning in groups is related to increasing the responsibility of students in order to create someone who thinks creatively. Collaborative Learning is based on a distinct epistemology and originates from social constructivism. Matthews (in Barkley, 2014:8) portrays the philosophical essence that underlies collaborative learning by stating that "Collaborative Learning can take place if educators and students work together to create knowledge". Collaborative Learning is a pedagogy which assumes that humans always create shared meanings and this process always enriches andbroadens their horizons.
The steps in applying the collaborative learning method according to Barkley, Cross and Major (Barkley, 2014: 9) consist of five steps, namely a) orienting students; b) forming study groups; c) arranging learning assignments; d) facilitate student collaboration; and e) score and evaluate collaborative learning that has been implemented. Collaborative Learning refers to a teaching method in which students in a group of varying skill levels work together in small groups that lead to common goals.

The interactive learning model is a method or learning technique used by the teacher in which the teacher plays the main role in creating an educational interactive situation, namely the interaction between teacher and student, student and student and with learning resources in supporting the achievement of learning objectives. According to Syah (1998) the interactive learning process teaches student involvement in totality, involving thoughts, vision, hearing and psychomotor (skills, one of which is writing). In the teaching process a teacher must invite students to listen, present visible media, provide opportunities to write and ask questions or responses so that creative dialogue occurs.

Online learning is part of e-learning, which is a broader concept than online learning, covering a series of applications and processes that use all electronic media to make vocational training and education more flexible. Online learning is learning that uses the internet, intranet and extranet, or learning that uses a computer network that is connected directly and has a wide (global) scope.

The method of online learning can be described as:

(1) Web Supported e-Learning, which is learning carried out face-to-face and supported by the use of a website that contains summaries, learning objectives, learning materials, assignments, and short tests. (2) Blended or mixed mode e-Learning, in which part of the learning process is carried out face-to-face and partly online. and (3) Fully online e-Learning format, namely the entire learning process is carried out online including face-toface meetings between educators and students which is also done online, where teleconference technology is usually an option.

Effective communication is the exchange of information, ideas, feelings that results in a change in attitude so that good relationships are established between the message giver and the message recipient. The effectiveness of a communication process can be seen from the achievement of the message sender's goals. In academic discourse the issue of communication effectiveness is quite often explained by the communication model of David K. Berlo (1960).

The famous communication model of Berlo, namely SMCR, contains the elements of Source, Medium, Channel and Receiver which all affect the effectiveness of communication. This Wilbur E. Schramm student included various elements of communication as his teacher had already expressed it, but Berlo put more emphasis on communication as a process. Collaborating 
between messages and channels can expand the concept of fidelity or accuracy.

Berlo views that everything can be a messenger, for example, through algorithms that are transmitted through computer equipment. Some energies can also carry messages such as electricity, air and light. To achieve effective communication, the communicant should pay attention to how to present a message, either verbally or nonverbally. It should also be noted which sounds are most effective in various situations.

What types of images or diagrams, animations, videos should be used to achieve effective communication in a variety of situations? To achieve effectiveness in communication, various combinations of these methods are needed. The concept of fidelity (accuracy) conveyed by Berlo, assesses that a communication process can be measured its effectiveness as seen from whether or not the goal of the sender of the message is achieved. This accuracy concept can be applied to all communications or components of communication.

The definition of online media is specifically related to the notion of media in the context of mass communication. The media - which stands for mass communication media - in mass communication has certain characteristics, such as publicity and periodicity. The definition of online media in particular is media that presents journalistic works (news, articles, features) online. Romli (2012) defines online media as “.... mass media that are presented online on internet websites".

According to Romli (2012), online media is a "third generation" mass media after printed media - newspapers, tabloids, magazines, books - and electronic media (electronic media) - radio, television, and film / video. Online media is an online journalistic product. Online journalism - also called cyber journalism is defined by wikipedia as "reporting of facts or events that are produced and distributed via the internet". Technically or "physically", online media are telecommunications and multimedia based media (computers and the internet). The online media category includes portals, websites (websites, including blogs), online radio, online TV, and e-mail.

A website is a web page that is interconnected which generally contains a collection of information in the form of text data, images, animation, audio, video or a combination of all that is usually made for personal, organizational and corporate purposes. From the definition of the website, it can be divided into two, namely static web and dynamic web. A web is static if the information content is fixed and the information content is only from the website owner, while the web is dynamic if the information content is always changing and can be changed by the website owner or user. Examples of static webs: company profile websites, while examples of dynamic webs like Facebook, Twitter, and other social media.

\section{RESEARCH METHODOLOGY}

This research on the development of education quality assurance is a research that uses qualitative methods in analyzing data, with the main idea that someone who is conducting research is also directly involved in the process and then consciously implements learning programs that have been designed to completion (Suwarsih, 1994 ). This research has many variants of learning context in the class or space used in the teaching and learning process carried out by lecturers in an effort to solve problems faced by lecturers in the learning process, improve student hard skills and soft skills by continuing to innovate using learning techniques to improve quality and student learning achievement.

Research Methods for Development and Quality Assurance of Education

The research data were collected through participatory observation in which the researcher was actively involved and became part of the classroom action research that was carried out. Other techniques that are also used are interviews, documentation and questionnaires. This type of classroom action research is collaborative. The researcher is also the teaching team to plan, identify, observe, and carry out the actions that have been designed. The research design used was a spiral system classroom action research with the Hopkins model as shown in Figure 1.

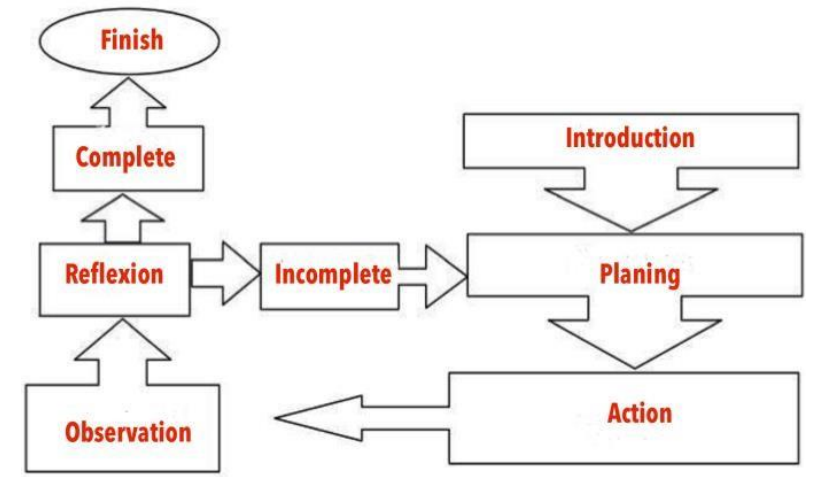

Figure 1. The PPMP design adapted from the Hopkin Model

This research was carried out in accordance with the Hopkins model research design which began with preliminary actions, then continued with planning, action, observation, and reflection. The research was conducted in two cycles. The results of the evaluation in the first cycle were still incomplete, so improvements were made in the second cycle. Reflection on the first cycle is carried out to determine steps for improvement in the second cycle.

\subsection{Strategy for Achieving Outputs}

\subsubsection{Research Cycle}

As explained above, this research was conducted in two cycles. Each cycle is carried out following procedures, namely planning, implementing actions, observing and reflecting. Through these two cycles, it can be observed that the students' ability increases using various media. The first cycle with an interactive 
learning assessment in the field and the second cycle online learning (the assessment reporting stage uses the ilearn.fisip.unand.ac.id portal).

\subsubsection{Research Subjects}

The subjects of this study were 36 students of the Public Relations Department of Communication Science, Andalas University, consisting of 24 female students and 12 male students.

\subsubsection{Research Time}

This research activity was carried out in one semester of learning in the even semester of the 2019/2020 school year. The first cycle of this research begins with a study contract to the midterm exam (UTS) starting January 20, 2020 - March 20, 2020 and the second cycle starts March 24, 2020 - May 24, 2020.

\section{RESEARCH RESULT}

\subsection{Overview of the G-PR Courses}

This G-PR course facilitates students to analyze how the G-PR deal with crises and problems, community service, and adjustments to online-based public relations performance. The G-PR learning method is Collaborative Learning that collaborates learning techniques to work together with others. Collaborative learning practice means working in pairs or small groups to achieve shared learning goals. Collaborative learning means learning through group work, not learning in isolation.

\subsection{Description of Learning Outcomes in the $\boldsymbol{G - P R}$}

For conceptual achievement, students are expected to have an understanding of the relation to the concept of public relations in the G-PR course, including understanding various elements of the G-PR, then identifying differences, similarities and phenomena in public relations studies, and being able to analyze, both conceptually and practically, assess the development of the public relations system. existing and use it as a source of excellence in the G-PR today in the practical and academic world. From the soft skill aspect, students are expected to be able to write good reviews / essays, be able to present the results of their thoughts clearly, be confident, independent, have discipline, ethics, and be able to work in teams.

\subsection{Learning Objectives}

The general objectives of learning the G-PR course:

1. Understand the various public relations concepts in the G-PR study.

2. Able to identify linkages between media relations and public information campaigns with government information service systems to the public.

3. Knowing and being able to explain the current development of the G-PR in establishing online-based public disclosure and Web 2.0.

4. Able to analyze and think critically in identifying crises in government, evaluating and planning strategic solutions in resolving crises.

\subsection{Research Results and Discussion}

\subsubsection{Cycle I Lecture process activities of the G-PR}

The G-PR lectures take place using the collaborative learning method between online learning and interactive learning, so that students are expected to have an understanding of the relationship between public relations activities directly in the study of the G- PR in the era of technology 4.0. Students are expected to understand the various elements of the G-PR, then identify differences, similarities and phenomena in public relations studies, and be able to analyze, both conceptually and practically, assess the development of the existing public relations system and use it as a source of excellence in current government public relations in the practical world as well as academic.

Table:. Components of the G-PR Course Assessment

\begin{tabular}{|c|c|c|}
\hline No & Component Assessment & Weight (\%) \\
\hline \multicolumn{3}{|c|}{\begin{tabular}{|l|l}
1. & Assessment of Results
\end{tabular}} \\
\hline \multicolumn{2}{|r|}{ a.|Mid Semester Exam (UTS) } & $25 \%$ \\
\hline \multicolumn{2}{|r|}{ b. Final Exam (UAS) } & $25 \%$ \\
\hline \multicolumn{2}{|r|}{ c. Group Duty } & $15 \%$ \\
\hline \multicolumn{2}{|r|}{ d.Individual Duty } & $10 \%$ \\
\hline \multicolumn{3}{|c|}{\begin{tabular}{l|l}
2. & Assessment Process (ATTITUDES)
\end{tabular}} \\
\hline \multicolumn{2}{|r|}{$\begin{array}{l}\text { a. Integrity, discipline, hard work, } \\
\text { courtesy/ethics/values, and confidence } \\
\text { (character), independence, critical and } \\
\text { analytical thinking, teamwork and oral } \\
\text { communication (soft skills) }\end{array}$} & $25 \%$ \\
\hline \multicolumn{2}{|c|}{ Total } & $100 \%$ \\
\hline
\end{tabular}

Source: Primary Data

Lecture activities in the field can be seen in the following picture:

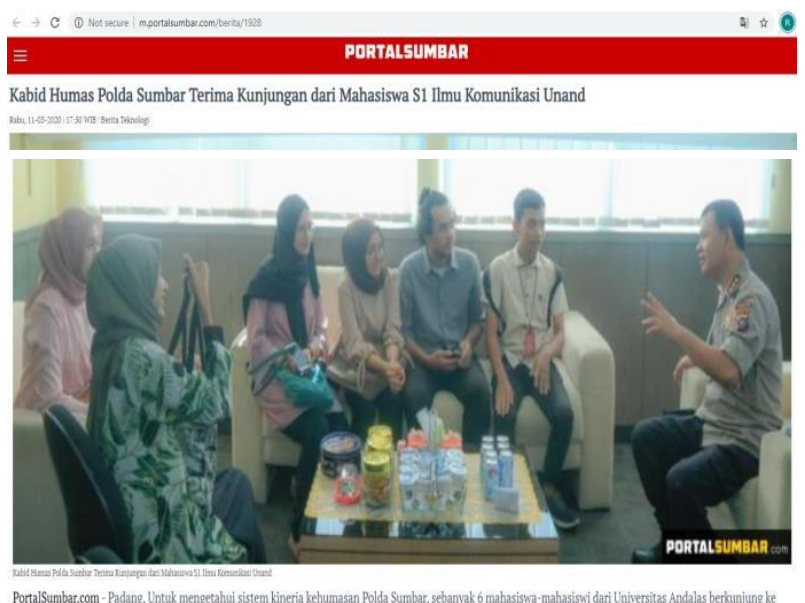

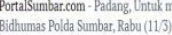

Figure 2. The GPR Course's Field Practice Activities

There are several problems faced in an effort to maximize student learning activities and achievement, including:

1. Students do not easily focus on learning because they 
cannot manage the use of gadgets.

2. This course is a course that analyzes the performance of the government, namely the Public Relations section, therefore it requires the ability to analyse.

3. Lecturers are still considering the appropriate learning technology so that students' soft skills are fulfilled.

4. Lectures are the dominant practice of producing content that requires a computer laboratory, as well as supporting hardware and software.

From these problems, appropriate learning methods are formulated, learning technologies that support the teaching and learning process, and appropriate assessment formulas so that the expected outcomes can be achieved. After completing the teaching and learning process of the $\mathrm{G}-\mathrm{PR}$, it is hoped that all students will get maximum scores.

The use of the Hopkins model research design begins with preliminary actions and then continues with planning, action, observation, and reflection. The research was conducted in two cycles. The results of the evaluation in the first cycle were still incomplete, so improvements were made in the second cycle. Reflection on the first cycle is carried out to determine steps for improvement in the second cycle. Reflection on the first cycle is carried out to determine steps for improvement in the second cycle. The research stages carried out are as follows:

\section{1) Planning}

Activities carried out at the planning stage include:

1. Develop a learning implementation plan using the debate method as a corrective action in learning

2. Prepare learning media in the form of case sheets and contemporary issues regarding government public relations.

3. Develop observation guidelines

4. Develop student evaluation tools.

2) Action

1. Initial Activities

In the initial activity, the lecturer prepared learning media and invited students to read the cases presented. Then arouse students' enthusiasm for learning by asking questions and answers about the issues given.

\section{Final Activity}

At the end of the lesson, the lecturer concludes the learning outcomes and explains the benefits of learning through the collaborative based learning method. and students have successfully completed the specified project.

\section{3) Field Observation}

The observation involved several parties, including members of the lecturer team, researchers, and peers. Observations are carried out when the learning process takes place based on the observation sheets that have been made by the researcher. Things that must be observed by observers are student activities during the learning process, and the learning process can be carried out in accordance with the learning implementation plan. Furthermore, analysis of the results of observations is carried out to determine the activeness of students, lecturers and the course of learning.

\section{4) Reflection}

All observations, student evaluations, and field notes were analyzed, explained, and concluded at the reflection stage. The purpose of reflection is to determine the success of the project-based learning process using various media technologies.

4.4.2. Cycle II Online Class Activities

The online lecture activities of the G-PR course prioritize learning activities using e-learning, which is a broader concept than online learning, which includes a series of applications and processes that use all electronic media to make vocational training and education more flexible. Online learning is learning that uses the internet, intranet and extranet, or learning that uses a computer network that is connected directly and has a wide (global) scope.

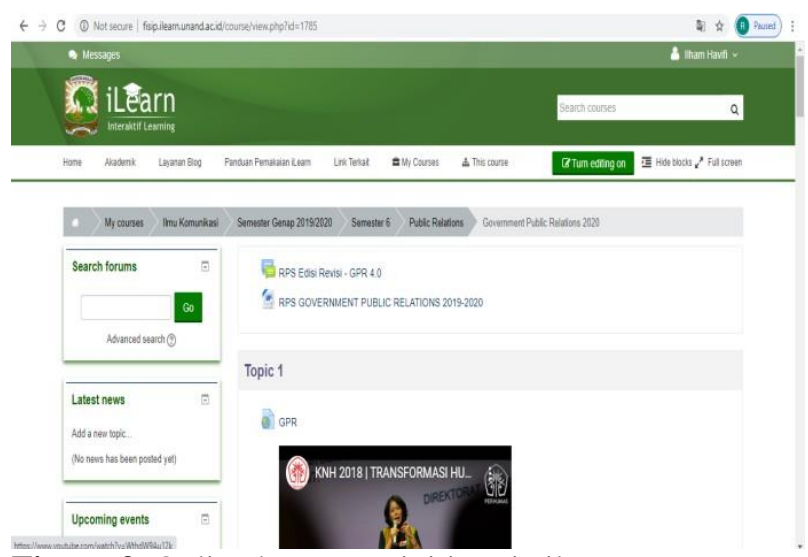

Figure 3. Online lecture activities via ilearn

This research was conducted through 2 cycles; each cycle carried out the following procedures: planning, implementing the action, observing, and reflecting. Through these two cycles, it can be observed that the student's ability to improve using various media can be observed. The first cycle with interactive learning assessment in the field and the second cycle online learning with the assessment reporting stage using the online learning portal of Andalas University with the site http://fisip.ilearn.unand.ac.id.

\section{CONCLUSION}

The design of the G-PR curriculum consists of a graduate profile, Graduate Learning Outcomes (CPL), study materials, courses in the form of a Semester Learning Plan (RPS) with conceptual outcomes, students are expected to have an understanding of the relationship between public relations concepts in G-PR studies. From the soft skill aspect, students are also expected to be able to write good reviews / essays, be able to present their thoughts clearly, be confident, independent, have discipline, ethics, and be able to work in teams.

Student activities in the field are observing the performance of government public relations within the scope of the regional government PR agency of West Sumatra Province. Students then report by making Student Field Practice Reports.

The G-PR lectures take place using the collaborative learning method (Collaborative Learning) between online 
learning and interactive learning, so that students are expected to have an understanding of the relationship between public relations activities directly in the G-PR studies in the era of technology 4.0.

Online lecture activities for the G-PR course prioritize learning activities using e-learning with the online learning method with assessment reporting stages using the Andalas University online learning portal with the site http://fisip.ilearn.unand.ac.id.

\section{REFERENCES}

[1] Arikunto, Suharsini, dkk. 2007. Penelitian Tindakan Kelas. Jakarta: Bumi Aksara.

[2] Alsa, Asmadi. 2003. Pendekatan Kuantitatif \& Kualitatif Serta Kombinasinya dalam Penelitian Psikologi. Yogyakarta. Pustaka Pelajar.

[3] Berlo, David K. 1960. The Process of Communication: An Introduction to Theory and Practice. New York:Holt, Rinehart and Winston.

[4] Bungin, Burhan (Ed.). 2008. Metodologi Penelitian Kualitatif. PT.Raja Grafindo Persada. Jakarta.

[5] Cangara, Hafied. 2009. Pengantar Ilmu Komunikasi. PT.Raja Grafindo Persada. Jakarta.

[6] Chatra, Emeraldy dan Rulli Nasrullah, 2008, Public Relations : Strategi Kehumasan dalam Menghadapi Krisis, Bandung: Maximalis.

[7] Effendi, Onong Uchjana. 1993. Ilmu, Teori, dan Filsafat Komunikasi. PT.Citra Aditya Bakti. Bandung

[8] Elizabert E. Barkley, K. Patricia Cross, Clarie Howell Major, Collaborative Learning Techniques (Bandung: Penerbit Nusa Media, 2014) di unduh pada tanggal 01 Maret 2020

[9] Hamijoyo, Santoso S. 2005. Komunikasi Partisipatoris. Humaniora. Bandung.

[10]Hanafi, Abdillah. $\quad$ (Penyusun).1981. Memasyarakatkan Ide-Ide Baru.Usaha Nasional. Surabaya.

[11]Harapan, Edi dan Ahmad, Syarwani. 2014. Komunikasi Antarpribadi: Perilaku Insani Dalam Organisasi Pendidikan. PT Raja Grafindo Persada. Jakarta.

[12] Heri Rakhmadi, Amir A. Gofur, Oddi Arma. 2015. $P R$ in Government - Bunga Rampai Program Kehumasan di Pemerintahan. Perhumas: Bamboedoea Komunikasi

[13] Littlejohn, Stephen W and Foss, Karen A. 2009. Teori Komunikasi. Penerjemah: mohammad Yusuf Hamdan. Salemba Humanika. Jakarta.

[14] Mordecai Lee, Grant Neeley, Kendra Stewart (Eds), 2012. The Practice Of G-PR. Boca Raton, $\mathrm{Fl}: \mathrm{Crc}$ Press
[15] Mulyana, Deddy. 2008. Ilmu Komunikasi: Suatu Pengantar. PT Remaja Rosdakarya. Bandung.

[16] Nasution, S. 1992. Metode Penelitian NaturalistikKualitatif.TARSITO. Bandung.

[17] Rubiyanto, Rubino. 2011. Metode Penelitian Pendidikan. Surakarta: FKIP UMS.

[18] Sari, Betty Wahyu Nilla. 2012. Humas Pemerintahan. Yogjakarta : Graha Ilmu

[19] Sugiyono. 2012. Metode Penelitian Pendidikan. Bandung: Alfabeta.

[20] Suwarsih, Madya. 1994. Panduan Penelitian Tindakan. Yogyakarta : Lembaga Penelitian IKIP Yogyakarta.

[21] Tubbs, Stewart L dan Moss, Sylvia. 2012. Human Communication. Penerjemah: Deddy Mulyana. PT Remaja Rosdakarya. Bandung. 